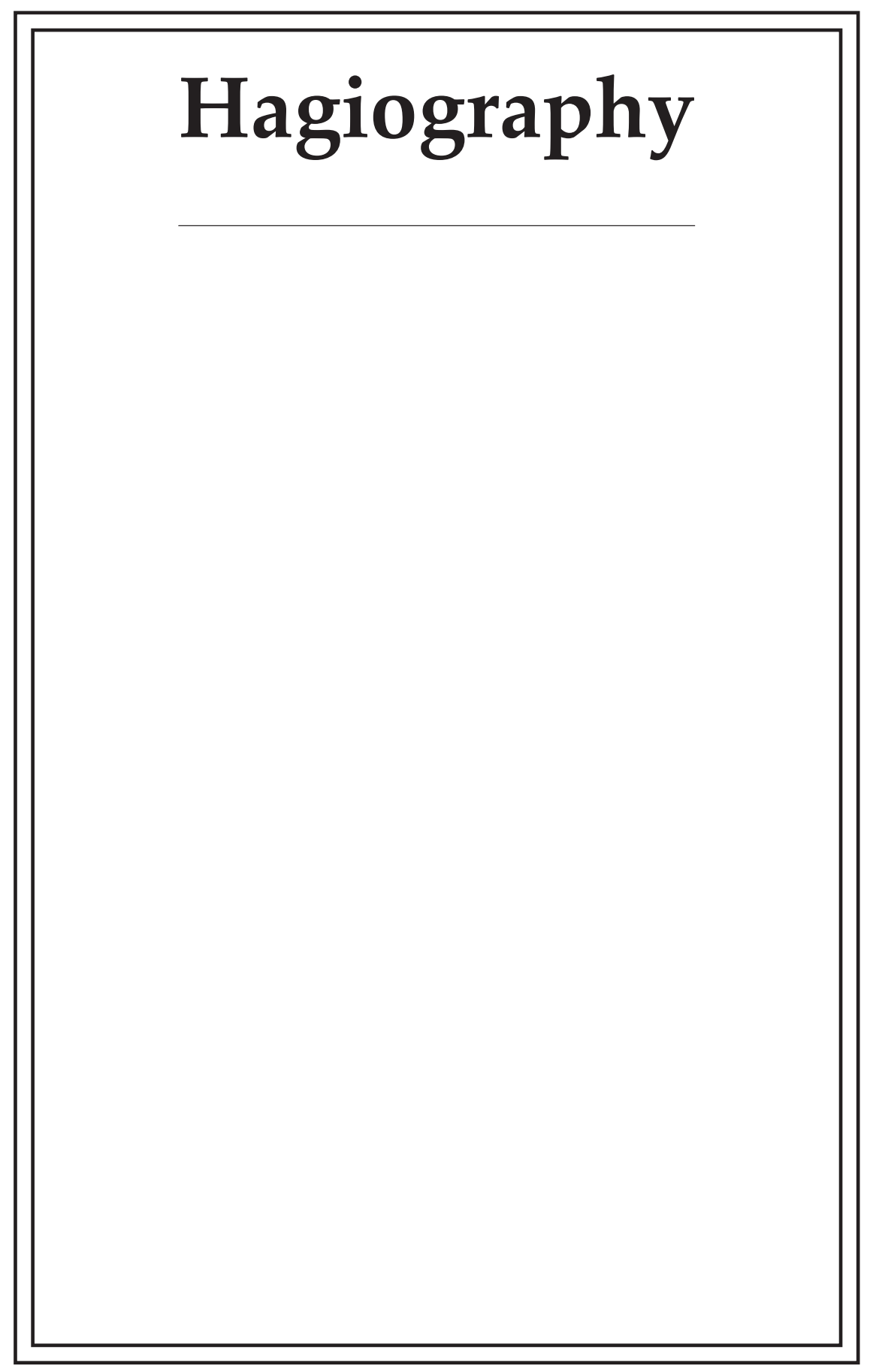

Downloaded from Brill.comఠ4/26/2023 02:48:26PM 
Andrey Moroz

Russian State University for the Humanities

Moscow

abmoroz@yandex.ru

\section{FOLKLORIC HAGIOGRAPHY AND THE POPULAR CULT OF SAINTS: FORMATION OF BELIEFS AND PLOTS}

When speaking about folkloric hagiography it is necessary to divide a peasant folk tradition, a modern city tradition and a tradition of people strictly observing church rules and traditions, frequently going on a pilgrimage etc. The article analyses folkloric hagiography as a part of a traditional folklore although it is not isolated from any other form of culture.

Usually hagiography means Christian didactic or liturgy literature about saints, as saints' lives and services. These two kinds of texts supply each other and contain basic Christian knowledge about saints. The rest is concluded in iconography, apocrypha and oral tradition. Indeed, many of literary lives of saints are based on oral tradition and lives of newly beatified saints must consider oral stories about the saint's miracles. Nevertheless, these oral sources are often elaborated and reviewed before they are used in a saint's life plot.

On the other hand, folk legends about saints may not correspond to literary stories at all; they represent another type of veneration of the saints. So, we should differ ecclesiastical and folkloric tradition although there is correspondence and mutual influence between them.

I use a term "Folkloric Hagiography" to designate a corpus of folk texts containing folk legends and tails, proverbs, magic and mantic texts (charms, calendar ritual songs, weather sign superstitions etc) as well as rituals and beliefs. Beliefs may be formed not only with hagiographical literature or oral narratives but with interpreting of visual component (icons), pseudo-etymology of saint's names etc.

As example we shall examine one of the most known "folkloric" saints. Elijah the prophet is one of mostly venerated saints in the folklore of orthodox Slavic peoples. His Russian folk hagiography is formed with a lot of different types of folk texts: 
1. Legends. St Elijah an St Nicholas discussed who of them is more worshiped by a peasant. They saw the peasant lighting a candle in front of Nicholas' icon ant not in front of Elijah's one in a church. Then Elijah said Nicholas that he was going to ruin all the harvest in the peasant's field with thunderstorm. St Nicholas went to the peasant and ordered him to sell the harvest just on the field, not reaping it. The peasant did this. After Elijah got to know it he decided to restore the crops. Nicholas said the peasant to buy it back. And so on. After few attempts of St Elijah to punish the peasant, Nicholas said him to light a candle for Elijah and the saint forgave him. ${ }^{1}$

2. Religious epic songs (духовные стихи). “Сказание о 12 пятницах" (Story about 12 Fridays)

$\begin{array}{ll}\text { Шестая великая пятница }- & \text { The sixth great Friday } \\ \text { Супротив Илия-пророка } & \text { Is before St Elijah, God's } \\ \text { Божия: } & \text { Prophet } \\ \text { В тую великую пятницу } & \text { On that great Friday } \\ \text { Взят Илия-пророк } & \text { Elijah Prophet was taken } \\ \text { на небеса } & \text { to the sky } \\ \text { На колеснице } & \text { On a fiery cart. }\end{array}$

3. Beliefs. The thunder is explained as a sound of St Elijah's cart, when he rides on the sky. ${ }^{3}$

4. Weather signs. On Elijah's day must be a thunderstorm. If not, it is considered as an bad sign. ${ }^{4}$

5. Taboos. It is strictly prohibited to maw grass and to work with hay on St Elijah's day. Otherwise he can fire hay stack. ${ }^{5}$

6. Calendar proverbs. Петр и Павел час убавил, Илья пророк два уволок ${ }^{6}$ (Peter and Paul took away a daylight hour, Elijah - two

(1) А. Н. Афанасьев, Народные русские легенды, Лондон, 1959, № 10, c. $39-42$.

(2) Голубиная книга. Русские народные духовные стихи XI-XIX веков, сост. А. Ф. СОЛОЩЕНКО, Ю. С. ПРОКОШИН, Москва, 1991, с. 190.

(3) С. Ю. ДуБРОВИНА, “Представления об Илье-пророке в традиционной культуре Тамбовщины," Живая старина (2002), № 1, с. 29.

(4) ALF, Arkhangelsk region, Kargopol district, Lyokshma.

(5) ДуБРОвИНА, “Представления об Илье-пророке,” с. 30. 
hours); Пришел Илья, наделал гнилья (Elijah came and made rottenness); На Ильин день до обеда лето, после обеда осеньв (On the day of St Elijah it is summer in the morning and autumn afternoon).

As we can see, the main feature of this saint is that he is a patron of thunderstorm and rain. This association is a result of an interpretation of a biblical episode, when Elijah was taken to the sky alive on a fiery cart. The plot is very well known due to widespread type of icon. Further development of this idea and the fact that the saint's day falls on the beginning of rainy period in Russia product legends of him where Elijah is described as a severe saint and beliefs that he controls weather, harvest and haymaking.

It is a common place in the historical, mythological, philological researches, that some Christian saint cults erased from cult of old pagan deities and they only have renewed pagan beliefs (as the Prophet Elijah is a reincarnation of thunder-bearers)..$^{9}$ This statement simplifies the problem too much. The very hagiographic literature and many hundreds years of Christian tradition give a great basis for saints cult raising and development without remarkable direct influence of pagan religion. In the case of Russian (or Slavic) folk culture we do not have any reliable data about Slavic paganism. There is not any direct correspondence between pagan and Christian beliefs, some of Christian feasts even were consciously set at the time of pagan ones (as St John the Baptist's birth), but if this correspondence exists, it is much more complicated and weaker, than it may seem. Instead of it (or besides) a lot of different factors have an influence upon folk cult of saints. One of the folkloric hagiography study objectives is to reveal, how and from what sources this cult erases.

(6) Archive of the Laboratory of Folklore. Russian State University for the Humanities (below ALF), Arkhangelsk region, Kargopol district, Trufanovo.

(7) ALF Arkhangelsk region, Kargopol district, Oshevensk.

(8) ALF, Arkhangelsk region, Kargopol district, Saunino.

(9) The most significant researches in this direction are: A. VAN GENNEP, Culte populaire des saints en Savoie (Archives d'ethnologie française, 3), Paris, 1973; В. В. ИвАНОВ, В. Н. ТОПОРОВ, Исследования в области славянских древностей, Москва, 1974; Б. А. УСПЕНСКИЙ, Филологические разыскания в области славянских древностей (Реликты язычества в восточнославянском культе Николая Мирликийского), Москва, 1982. 
Another aberration, widespread when written lives of saints are concerned, is a thesis, that lot of them are based on oral legends. It is frequently told by ancient literature researchers when they cannot indicate certain source for episodes of the text being analyzed. ${ }^{10}$ But absence of a prototype is not yet an indication on folkloric source - it only states absence of written one. We can see different kinds of correspondence between oral tradition and literary hagiographical texts: written saint life may be based on oral legends and vice versa, folk narratives often are retellings of written texts that later were treated, updated with new details and became legends. The very characteristic example of this relation between oral and written texts is the Life of St Cyril Chelmogorsky ${ }^{11}$ and folk legends about him. ${ }^{12}$ The literary life of this saint is based on life of another saint hermit - St Nilus Stolobensky. Since the real life of St Cyril is unknown, his hagiographer about four centuries later, in the $17^{\text {th }}$ century, composed a "biographical" part of the saint's life of some episodes of St Nilus's life. The original part of the St Cyril's life describes miracles, that occurred in the time when the hagiographer lived. Oral legends registered in villages close to former St Cyril's monastery describe only the Saint's life, not miracles after his death, i. e. they are completely based on the written text. It does not mean, that these legends are close to text retellings of the literary life. Legends contain a lot of typically folkloric features, but they have literary origin.

In some cases oral tradition and literary saint's life do not have any correspondence. Oral legends that are commonly known in the village of Oshevensk, where St Alexander Oshevensky has founded a monastery, and in neighboring villages have no correspondence with

(10) G. H. DOBLE, "Hagiography and Folklore," Folklore. Transactions of the folk-lore society, 54.3 (1943), pp. 329-330; А. А. ДМИТРИЕВ, Житийные повести Русского Севера как памятники хитературы XIII-XVII вв., Ленинград, 1973, с. 259; А. С. ЛАВРОВ, Колдовство и религия в России 1700-1740 г2., Москва, 2000, с. 221; С. А. ИвАНОв, Блаженные похабы. Культурная история юородства, Москва, 2005, с. 295.

(11) <Иерей ИОАНН,> “Житие преподобного Кирилла, игумена челмогорского, каргопольского чудотворца. Предисловие, подготовка текста и комментарии А. Б. Мороза," Альфа и Омега. Ученые записки Общества для распространения Священного Писания в России, № 3 (17) (1998), c. $200-236$.

(12) А. Б. МорОз, Святые Русского Севера. Народная агиография, Москва, 2009, с. 379-386. 
his literary life. This life is completely unknown for these villages inhabitants.

The problem of sources, priority of oral or written tradition and their mutual influences is only one aspect of folkloric hagiography study. Another one is how is sanctity understood by popular culture: what means 'saint', what is his place and role among other supernatural beings and what ritual forms of their veneration are determined with.

The contemporary actual mythological system in Slavic peasant folk tradition is quite archaic by genesis. Saints, although sanctity has also nearly two thousand years history (one thousand among Slavs), had to be incorporated into existing mythological system. So, saints have their own role in this system but correspond to other characters.

- There is semantic and functional relation of saints and demonic characters. In some cases they perform the same roles. For example, in the Russian North a belief exists, that the herdsman, performing the rite of the first pasture contracts with лешиц (forest daemon) or with some saints, which pasture a herd themselves under certain condition. If a herdsman observes conditions of the contract, he should not have to follow the herd, he only drives it out in the morning to forest and he collects in the evening - а леший or saints do a rest. A violation of the agreement leads to a death of the cattle and even to his own death. ${ }^{13}$

- Saint corresponds with deceased. This correspondence has two aspects: a saint corresponds with a "normal deceased" and in other cases - with those who died an unnatural death. Dead ancestors are venerated as patrons, every commemorative day peasants have to go to their tombs and to commemorate (i. e. to feed them). This provides their assistance in some situations. The same is done at saints' feasts if there are some sacred places attributed to a saint: food is brought to the sacred place and partially eaten, partially lost there for a saint.

Those who was killed or dead young because of sudden illness, or suicided constitute a special category of dead. They are treated by tradition as terrible and dangerous creatures that can

(13) А. Б. МорО3, “Севернорусские пастушеские отпуска и магия первого выгона скота у славян," in: Восточнославянский этнолингвистический сборник, Москва, 2001, с. 235-240. 
harm and even kill a human being. Crosses are located at the places of their death or burial outside cemetery to consecrate these fearful locations. Holy places devoted to saints look quite similarly (cross, offerings etc). Some similarity may bee also seen in a cult of few Russian saints, about whom was not known anything. The cult in these cases began from finding of unknown bodies (cast ashore in the case of St John and Longinus Yarengsky or floated down a river on an ice floe as in case of St John Borovichsky). When bodies of these saints were found they were buried in the same way as the killed or drowned people are buried: at the same place, where they were found (not in a cemetery), a cross or a chapel was built over the tomb.

- Saints are being perceived as a kind of cultural heroes. In legends they often create certain landscape objects, settlements and natural phenomena, give names to places - for example it is a widespread opinion that saints find or dig springs or wells and sanctify them. If any saint is especially worshiped in any location, he is usually treated as a nominator of villages, rivers etc or as a creator of springs, roads, rivers. Near the village of Oshevensk a monastery of St Alexander Oshevensky was built in by this saint $16^{\text {th }}$ century. According to legend St Alexander came first to another part of the great village and was banished by inhabitant. He went to the other end of thee village but previously damned peasants: "You will live near the water, but without water." Since this moment the nearby river flows under ground. In reality it has karstic bottom and un summer, when it is not too much water, it really goes down into a crack in the river bottom. The way he went to the actual monastery place is not overgrown, both these places as well as some stones where his footprint is visible are venerated as sacred ones. ${ }^{14}$

- A saint as a "trickster." There are saints who have a reputation of evil and vengeful. The most common character like this is St Cassian of Rome, whose feast is celebrated on February 29. This fact as well as an interpretation of his name connected with Slavic root кос- (косой - 'skew', 'squint' or 'wrong') caused the idea that he is squint-eyed and evil. It is believed that a leap

(14) Моро3, Святые Русского Севера, с. 341-378. 
year is always unhappy: На что Касьян взглянет - всё вянет. This idea is supported by legends about Cassian saying that he always stays in hell and keeps its gates closed, and he is only left to go from there once every 4 years on his "name-day." 15 The fact his "name-day" is only once every 4 years is explained in another legend: Cassian refused to help peasant pull a cart out of the mud, because he was going to God and did not want to dirt his clothing. St Nicholas vice versa helped him and dirtied his clothing. God seeing that asked Nicholas what is the matter and after his explication damned Cassian and blessed Nicholas, so the former has "name-day" one time every four years, and the latter - two times a year. ${ }^{16}$

Thus, the traditional knowledge about saints is mainly formed with literary lives transformed by oral tradition, and proper folk legends. Written texts in oral redaction loose own entirety and only few episodes remain, for some reason suitable to folkloric narratives and world view. These episodes loose some bookish details and obtain new ones that seem important and corresponding with a folk tradition.

In the life of St Cyril Chelmogorsky peasants came to banish him from the place where he settled. They tried to drag down his cell from the hill into the swamp. The chain, they used, broke, and they fell down into the swamp and drowned. In folk narratives these peasants become eather daemons, or inhabitants of the certain nearest village (in this case a rivalry between two villages is meant). The certain swamp is shown near the place where St Cyril's monastery was, as the swamp, where the daemons drowned. Narrators usually add that it dangerous to walk there (in reality it is not), because after daemons' fall the swamp became bottomless.

The very important features of folk legends or written lives cited is their correlation with local landscape. It is necessary for tradition bearers to feel correspondence between saint's life and their own ones. That is why everything is described in hagiographic legends should be strictly connected to landscape. Even if venerated saint never has been to the area where he is worshiped, different landscape objects are connected with him: you may see stones where he stood,

(15) Н. М. МЕНДЕЛЬСОН, “К поверьям о св. Касьяне,” Этнографическое обозрение (1897), № 1, с. 1-2.

(16) А. Н. АфАНАСьЕВ, Народные русские легенды, № 11, с. 42-43. 
springs where he drank, path, which is not overgrown with plants since he passed etc.

Rites which are a form of saints veneration are based on repetition of what the saint has done according to legends. At the saint's feast or on some other days people walk along the saint's pass, drink water from the saint's spring, step on the footprint left by a saint on stone etc. In this manner the saint's lifetime and a situation of his visit to a village are renewed.

Another type of his ritual veneration is a communication with him: bringing some food to feed him or some things ex voto to the place, where the saint was living, as it is considered.

There is often a great difference between the folkloric cult of saints and a common knowledge about them. The first one may be based only on a saint's feast, customs traditionally connected with it and on a feast name that is interpreted in some specific manner. A saint's life may be completely unknown to tradition bearers although the feast of the same saint may be one of the most venerated in the same location. The very name of a saint may be associated only with a feast, because most days devoted to saints are called in colloquial language with saints' names: for example, asking who is saint George, you are answered, that it is a festival. This substitution of saint with his feast may be a base of a new "hagiography," that does not correspond to saint's real, literary or folkloric life. It is quite common that saints whose feasts are nearby in calendar, become relatives in folk beliefs. In Bulgaria St Nicholas has two sisters - Savva and Barbara (although Savva is male his name may be understood as female). ${ }^{17}$ The same genesis, as I think, has Russian proverb Наготовить как на Маланьину свадьбу (to have cooked [a lot] as for Melania's wedding). St Melania's day is December 31, so she marries St Basil of Caesarea, whose day is January 1. Lingual interpretations of saints names also create new beliefs and even new saints. In Occitan the St Agatha name sounds as santo Gato (like saint Cat), that is why is believed that this saint may appear as a cat. ${ }^{18}$ In Russian tradition the day of Beheading of John the Baptist is prohibited to cut vegetables in the garden, because someone hidden there will cut your head. This

(17) Р. ПоПов, Светичи и демони на Балканите. Сравнително етноложко изследване. София, 2002. С. 69.

(18) V. AlfORD, "The cat saint," Folklore. Transactions of the folk-lore society (1941), No 3, p. 178. 
someone is associated with St John and even may be replaced by him: it is said that St John will cut the violator's head. The popular fest name is Головосек (head-cutter) and this Головосек became a specific character, a saint.

Thus, a pseudo-hagiography is arising, that is not connected with the saints lives. ${ }^{19}$

One more example, that shows how all the described system works. The life St Nicetas the Stylite in Pereslavl Zalessky is written much later than he lived (it is not known exactly when he really lived, but in some manuscripts is written it was in the $12^{\text {th }}$ century). According to his life he was a tax-collector (it is a very remarkable symbol for hagiography itself but not for folkloric one) and was well known as a great sinner. Once he had a vision: he saw some parts of human bodies in the soup his wife was cooking. He repented and went to the nearest monastery of St Nicetas martyr. Prior told him to stay for three days at the monastery entrance and to confess his sins to everyone who passes by him. On the third day monks had not seen him by the entrance and a little later have found him in the swamp. Nicetas was sitting there nude so that mosquitoes and flies could bite him. He was taken to monastery, became a stylite there and was killed later. Nicetas' monastic exploit as a stylite - is quite obscure story. In fact there was no any pillar. He lived in a small cell, dug in the ground. In early life manuscripts of the end of the $16^{\text {th }}-17^{\text {th }} \mathrm{c}$. he is not called stylite, this suffix is added in the mid. $17^{\text {th }} \mathrm{c}$. Just at the end of the $17^{\text {th }} \mathrm{c}$. a brick pillar was built over Nicetas' cell and later a chapel was built around the pillar in the $18^{\text {th }} \mathrm{c}$. His cell is situated under the chapel. What was primary - name or pillar - is not well known, but I suppose that the name was. My hypothesis why it occurred is this. It might occur due to a word cront (hill) wrong understood by a scribe: Никита поиде на слопь монастырский и ископа себе столпь (Nicetas went to the hill and dug himself a pillar). It is impossible to dig a pillar, but an ancient Russian noun cront and столnъ sound similarly, so столnъ could substitute another noun (like "cell") under the influence of nearby and similar cront. Howbeit, the pillar became a holly place and people began to come to it and to circuit it in order to be healed.

(19) A great collection of quasi-saints is described in: J. E. MERCERON, Dictionnaire des saints imaginaires et facétieux, Paris, 2002. 
The episode with swamp and mosquitoes was the beginning of St Nicetas' biography as a saint, but it is the only one perceived and reviewed by folklore. In fact it substitutes all saint's biography. According to folk tradition existing in villages near the monastery, Nicetas went to a certain swamp (indicated by inhabitants), where finally was dead. His body was found thanks to visible pillar formed by mosquitoes hanging in the air. According to the legend this day became Nicetas' feast (May 24) and it is now treated as a mosquito day. The summer activity of mosquitoes begins just this day. The mosquito pillar (столб) appears in the context of folk idea of these insects and some other beliefs:

1. in the beginning of summer mosquitoes may be seen in a shape of a pillar (комары в воздухе столбом стоят) - this presages a good sunny weather.

2. it is usual for folklore to mark different borders, beginning and end of different actions and natural phenomena with calendar dates (snakes go underground on Holy Cross Day; harvest ends at Nativity of the Virgin etc).

3. Nicetas is called stylite (столиник).

As a result we have a new legend plot much better known than the written life content, although a new edition is being sold in the monastery and in the town. One more detail shows that everything that was described above is not an curious occasion but a system: in another region - near Kargopol (Arkhangelsk region), about 800 km far from Pereslavl, there was a chapel in a village consecrated to St Nicetas. Inhabitants of the village also know the legend of the saint bitten to death by mosquitoes and observe a day of May 24 as a mosquito day, when they begin to bite people.

So, we may state, that episodes to be interpreted and transformed into legend plots are not selected occasionally, but according to some mechanisms of folk narrative tradition, that adopts literary texts and put them in correspondence with folkloric world view.

\section{SUMMARY}

The article introduces and motivates the concept of "Popular hagiography," discusses the features of the vernacular cult of saints, the relationship between the literary and folkloric hagiography, specific conception of holiness, sources of hagiographic plots and texts in folk culture. Folk saints cult and the knowledge about saints are based on the recep- 
tion of the literary hagiography, on the interpretation of iconographical detailes, on the semantization of saints' names or the names of their feasts. The popular hagiographic legends may be based on other folkloric genres. Folk cult of the saints is formed with hagiographical texts: ritual practices either repeat saints' actions described in legends, or realize communication with them, as well as communication between alive and deceased is being realized during funeral ceremonies. 